\title{
Replies to Professor Weeks
}

\author{
Paul Sigmund \\ Department of Poltics, Princeton Unversity
}

The issue between Professor Weeks and myself is basically one of degree. My article maintained that "to a considerable degree" the Chilean military has "returned to their earlier tradition of professionalism, legalism and constitutionalism" (Sigmund, 2003: 249). It criticized Brian Loveman's description of Chile as a "protected democracy" (Sigmund, 2003: 246), and Professor Weeks' claim that if the Chilean military's "salient interests" are threatened, "intervention will be considered not just necessary but patriotic" (Sigmund, 2003: 248).

I agree that much remains to be done to give legal and constitutional recognition to civilian supremacy. My article, however, described how much progress had already taken place in this area- progress that I would not describe, as does Professor Weeks in the title of his 2003 paper, as "Inching Toward Democracy. "As for specifics, the National Security Council is now practically defunct, the renegotiation of the copper law which before the 1973 coup was not even discussed is now definitely on the political agenda, the appointed senators are on their way out, and Michelle Bachelet, a victim along with her family of repression by the military, is Minister of Defense and a likely presidential candidate.

Is it or is it not true in Chile today that "the army can no longer exert the threat of a coup to extract concessions from the civilian government." (Sigmund, 2003: 249). As it did in the 1990's? For Professor Weeks the glass of the transition to civilian rule is $2 / 3$ empty: for me it is $2 / 3$ full.

\section{REFERENCES}

Sigmund, Paul. 2003. "The Chilean Military: Legalism Undermined, Manipulated, and Restored". Revista de Ciencia Politica XXIII (2): 241-250.

Paul E. Sigmund is professor at the Princeton University. His publications include The Overthrow of Allende and the Politics of Chile (Pittsburgh, 1977), Multinationals in Latin America: The Politics of Nationalization (Wisconsin, 1980). The Military Institution in Latin America [with Robert Wesson et al.] (Praeger, 1986), the English translation of Alain Rouquie_L"Etat Militaire en Amerique Latine (The Military and the State in Latin America, California, 1987), The United States and Democracy in Chile (Johns Hopkins, 1993), and "Approaches to the Study of the Military in Latin America," Comparative Politics, October, 1993.

(E-mail: paulsig@Princeton.EDU) 